ks. Marek Kowalczuk

Uniwersytet w Bialymstoku

$0000-0002-4529-2161$

DOI: $10.15290 /$ std.2019.05.06

\title{
PARADYGMAT KONCYLIARNOŚCI W Dz 15,1-29
}

\section{THE CONCILIARITY PARADIGM IN ACTS 15.1-29}

While writing the Acts of the Apostles, Lukas followed the ancient historiographers which often told stories on the basis of which some paradigms were created. Therefore, the paradigms of characters, history and Church community can be found in the Book. In this paper, the author focuses on the story of the Council of Jerusalem (Acts 15, 1-29). As a response to the crisis arising around the dispute over a necessity of circumcision, the meeting can be treated as a paradigm of a conciliar way of confronting the conflicts concerning faith and practice in the context of community.

Key words: Acts 15,1-29, Antioch crisis, Council of Jerusalem, collegiality.

W kompozycji Dziejów Apostolskich rozdział 15, opisujący zgromadzenie Kościoła w Jerozolimie zajmuje centralne miejsce, jako „historia jego księgi” Autor księgi nadaje temu wydarzeniu charakter epokowy: w tym miejscu zostaje powszechnie przyjęty zarówno uniwersalny charakter Kościoła, jak i zasadniczy stosunek do przepisów religijnych ówczesnego judaizmu. Z naszego punktu widzenia interesującym aspektem jest sposób, w jaki sytuacja konfliktowa jest rozwiązywana. Jakkolwiek stosowanie określenia „sobór” w odniesieniu do zgromadzenia opisanego w Dziejach Apostolskich jest pewnym anachronizmem², to jednak zarówno w opisanej scenie jak i w ostatecznej odpowiedzi, jaka wysłana zostaje kościołowi antiocheńskiemu wyraźnie widać tworzenie się nowego stylu

\footnotetext{
$1 \quad$ G. Schille, Die Apostelgeschichte, Leipzig 1989, s. 327.

2 Por. J. Gnilka, Paweł z Tarsu. Apostot i świadek, Kraków 2001, s. 129.
} 
mierzenia się $z$ kontrowersjami. Polega on przede wszystkim na przedstawieniu różnych zdań na forum publicznym, a następnie na wypracowaniu osądu, który interpretowany jest nie tylko jako rezultat wspólnotowej próby poszukiwania kompromisu, ale także jako przejaw działania Ducha Świętego we wnętrzu Kościoła $(\mathrm{Dz} 15,28)$. Ten sposób podejścia do sytuacji konfliktowych można określić jako „protokoncyliaryzm”.

Warto już na wstępie zauważyć, że opowiadanie zawarte $\mathrm{w} \mathrm{Dz}$ 15,1-26 odpowiada do pewnego stopnia relacji Pawła z Ga 2,1-10. Pomiędzy tymi relacjami zachodzą jednak pewne istotne różnice. Przede wszystkim w Dziejach Apostolskich konflikt powstały w Antiochii jest przyczyną odbycia się opisywanego zgromadzenia. Z kolei w relacji Pawłowej sytuacja konfliktowa powstaje już po osiągnięciu zgody, wskutek działań wysłanników Jakuba i dwulicowego zachowania Apostoła Piotra. Dodatkowo problem komplikuje kwestia daty powstania Listu do Galatów, wokół której do dziś toczą się dyskusje. Z tego powodu trudno ustalić rzeczywistą datę zgromadzenia określanego jako Sobór Jerozolimski. Zazwyczaj wskazuje się na lata 48-49 lub 51-52 po Chr ${ }^{4}$. Celem niniejszego artykułu nie jest próba odnalezienia satysfakcjonującego rozwiązania wspomnianej kwestii. Faktem jest, że Łukasz w swojej relacji zachowuje metodę właściwą historiografii hellenistyczno-rzymskiej. Z tej perspektywy kreuje on swoją narrację jako historię paradygmatyczną ${ }^{5}$ w której w określonych scenach opisywana jest rzeczywistość rozwoju Kościoła w pierwszym okresie jego istnienia.

\section{Istota konfliktu}

Bezpośrednią przyczyną zgromadzenia w Jerozolimie, według narracji Dziejów Apostolskich, była sytuacja określana jako konflikt antiocheński. Spowodowali ją przybysze z Judei, których nauczanie stało się przyczyną podziału w gminie chrześcijańskiej odnośnie do konieczności poddania się obrzędowi obrzezania. Ci przybysze, określani jako „jacyś” (tines) uznawali przestrzeganie

Tak określa to zgromadzenie C.K. Robertson, Proto-Conciliarism in Acts 15, "Sewanee Theological Review" 2018, 61/2, s. 417-423.

4 Spośród polskich autorów tę pierwszą datę przyjmują np. W. Chrostowski, Między Synagoga a Kościołem. Dzieje św. Pawła, Kraków 2015, s. 135-162; F. Mickiewicz, Działalność misjonarska św. Piotra poza Palestyna w świetle literatury nowotestamentowej, „Collectanea Theologica” 2019, 89/3, s. 89. Na datę późniejszą wskazuje np. W. Rakocy, Pawet Apostot. Chronologia życia i pism, Częstochowa 2008, s. 164-166.

5 Zob. A. J. Najda, Historia paradygmatycznaw Dziejach Apostolskich, Warszawa 2011, s. 175 177. Autor wskazuje także na różnice, jakie istnieją pomiędzy historiografią klasyczną a Łukaszową. Najistotniejszą z nich jest fakt, iż Łukasz pisze swoje dzieło z perspektywy teologicznej, jako „związek spowodowanych i kierowanych przez Boga wydarzeń”. 
Prawa Mojżeszowego jako niezbędne do tego, by móc osiągnąć Zbawienie. Ostrość konfliktu sprawia, że do Jerozolimy zostają wysłani Barnaba i Paweł, wraz z kilkoma towarzyszami, aby przedstawić tę kwestię „Apostołom i starszym”. Warto przy tym zwrócić uwagę na fakt, że przedstawicielami Kościoła antiocheńskiego są reprezentanci tylko jednej strony istniejącego sporu. Już w czasie zgromadzenia w Jerozolimie oskarżenie ich przeciwników jest przedstawione po raz kolejny. W tym przypadku doprecyzowane jest, że jego autorami są ci spośród jerozolimskich chrześcijan, którzy - podobnie jak Paweł - przed nawróceniem należeli do stronnictwa faryzeuszy.

Inaczej przedstawiona jest chronologia sporu w Liście do Galatów. Paweł stwierdza, że powodem jego przybycia do Jerozolimy było specjalne objawienie, przy czym tekst nie precyzuje, czego miałoby ono dotyczyć. Jako swoich towarzyszy wymienia Barnabę i pochodzącego z pogaństwa Tytusa. Konflikt rozpoczyna się dopiero na miejscu, za sprawą „fałszywych braci” (hoi pseudadelfoi), którzy, bezprawnie dostawszy się na spotkanie, domagali się przyjęcia znaku obrzezania. Rezultatem tej sytuacji było bardziej prywatne spotkanie z tymi, „którzy cieszą się poważaniem” (oi dokūntoi einai ti), w trakcie którego Paweł przedstawił im tę naukę, którą głosił dotychczas. Spośród tego grona na czoło wysuwają się postaci Apostołów Jakuba, Piotra i Jana. To spotkanie zakończyło się akceptacją nauki Pawła. Właściwy konflikt w Antiochii powstaje dopiero później, kiedy do miasta przybywają Piotr i niektórzy z otoczenia Jakuba. Pierwszy z nich początkowo uczestniczy w posiłkach razem z nawróconymi z pogaństwa, później jednak - spotykając się z krytyką judeochrześcijan (tekst Ga 2,12 określa ich jako „ci z obrzezania”) - odsuwa się od nich. Widzimy zatem, iż w tym przypadku konflikt dotyczy raczej praktyki dietetycznej, związanej z zachowywania przepisów koszerności. Jak jeszcze zauważymy, koresponduje to $z$ orzeczeniami Soboru Jerozolimskiego, które w dużej części dotyczą tej właśnie materii. Ostatecznym rozwiązaniem konfliktu w narracji Pawła jest dopiero publiczne zwrócenie uwagi Piotrowi na jego nieszczere zachowanie.

Jakkolwiek różnice w obydwu opowiadaniach są istotne, to nie można ukryć faktu, że podstawowym źródłem sytuacji konfliktowej jest pytanie o znaczenie Prawa Mojżeszowego dla chrześcijan. W Dz przygotowanie do rozwiązania tej kontrowersji zajmuje sporo miejsca. Przede wszystkim musimy zwrócić uwagę na wydarzenia związane z wizytą Piotra w domu Korneliusza (Dz 10). Także ta sytuacja powoduje niezadowolenie przedstawicieli judeochrześcijan (tekst Dz 12 określa ich znowu jako „tych z obrzezania”), przed który Piotr składa obszerne wyjaśnienia, broniąc swojego postępowania. Kolejną sytuacją konfliktową staje się wizyta Pawła i Barnaby w Antiochii Pizydyjskiej, w trakcie której dochodzi do otwartego konfliktu pomiędzy Apostołami a przedstawicielami 
gminy żydowskiej. Jej rezultatem jest decyzja o zwróceniu się z głoszeniem Ewangelii do pogan.

Powstaje więc wrażenie, że istotą problemu były konflikty o charakterze etnicznym. Taką tezę potwierdzają również inne fragmenty Dz. Już kilka miesięcy po wydarzeniach Pięćdziesiątnicy rodzi się podział odnośnie do rozdawania jałmużny $(\mathrm{Dz} 6,1-7)$. Linia jego podziału przebiega według granic raczej językowych niż religijnych, gdyż użyte w tekście określenie „helleniści” (hoi hellēnistoi) odnosi się do tych Żydów, którzy posługiwali się językiem greckim i uczęszczali do synagog, w których liturgia odbywała się właśnie w tym języku ${ }^{6}$. Również mowa Szczepana wydaje się dotykać tej linii podziału, zwłaszcza w tej części, która zawiera krytykę Świątyni. Rozdźwięk ten staje się coraz bardziej widoczny wraz z dynamicznym rozprzestrzenianiem się chrześcijaństwa wśród ludzi niebędących etnicznymi Żydami. Jako przykład może nam posłużyć misja diakona Filipa oraz Piotra i Jana w Samarii (Dz 8,4-24), nawrócenie dworzanina etiopskiego ( $\mathrm{Dz} 8,25-40)$ czy wspomniana powyżej wizyta Piotra w domu Korneliusza?. Warto przy tym zaznaczyć, że znakiem włączenia do nowej społeczności stawało się za każdym razem przyjęcie przez dana osobę chrztu, nie zaś poddanie się wymogom Prawa.

Sam fakt obrzezania odgrywał istotną role w życiu religijnym Narodu Wybranego: był znakiem przymierza, oczyszczenia i włączenia do Ludu Bożego. W czasach machabejskich wielu Żydów gotowych było narazić swoje życie po to, aby zachować ten znak posłuszeństwa wobec postanowień Boga (1 Mch 1,60-61). Nie wszyscy jednak podzielali tak radykalne poglądy odnośnie do kwestii obrzezania. Filon z Aleksandrii przyznaje, że wielu jego pobratymców nie poddaje się temu obrzędowi, a mimo wszystko nie spotykają się oni z potępieniem $z$ jego strony. Zna on także praktykę epispazmu, za pomocą której można było pozbyć się zewnętrznych skutków obrzezania ${ }^{8}$. Podobne opinie można znaleźć także u Józefa Flawiusza, w przytoczonej przezeń historii Izastesa, który - jakkolwiek dokonał konwersji na judaizm - to jednak nie poddał się wspomnianemu obrzędowi ze względu na obawę przed poddanymi ${ }^{9}$. O ile więc w samej Judei przyjęcie znaku obrzezania uważane było za warunek sine qua non bycia Żydem, o tyle opinia te nie była powszechnie przyjmowana przez

6 Zob. F. F. Bruce, The Book of Acts (New International Commentary on the New Testament), Grand Rapids 1988, s. 214.

7 Por. C. Bennema, The Ethnic Conflict in Early Christianity. An Appraisal of Bauckham's Proposal on the Antioch Crisis and the Jerusalem Council, „Journal of the Evangelical Theological Society" 2013, 56/4, s. 754-756. 
Żydów z Diaspory ${ }^{10}$. W pewnych kręgach zatem tego rodzaju praktyka mogła być postrzegana jako jeden ze zwyczajów o charakterze etnicznym, nie zaś jako bezwzględnie wymagana praktyka religijna. Żądanie przyjęcia obrzezania przez chrześcijan pochodzących z pogaństwa wydawało się być nieuprawnioną próbą narzucenia własnych zwyczajów jako obowiązujących wszystkich.

Jakkolwiek główna oś konfliktu przebiegała według podziałów etnicznych to jednak nie można zgodzić się z tezą, że podział dotyczył jedynie tej kwestii. Kwestią o znaczeniu fundamentalnym była tu raczej samoświadomość rodzącego się Kościoła, który pojmował swoją misję jako uniwersalistyczną. W tym aspekcie istotne było ustalenie, w jakim stopniu chrześcijan obowiązują regulacje Prawa Mojżeszowego. W praktyce głoszenia Ewangelii niebagatelną rolę odgrywa odwołanie do pism Starego Testamentu, które miały znaleźć wypełnienie w osobie Jezusa Chrystusa. W tym aspekcie Kościół jawił się raczej jako spadkobierca tradycji judaizmu niż jako twór zupełnie nowy. Również udział Apostołów w kulcie świątynnym zdaje się wpisywać w ten sposób interpretacji rodzącego się chrześcijaństwa. Z drugiej strony, wspomniana misja ewangelizacyjna skierowana do pogan wskazuje, że od początku chrześcijanie pojmowali, iż przesłanie Chrystusa nie jest ograniczone jedynie do Żydów, lecz obejmuje całą ludzkość. W tym kontekście rozwój Kościoła i jego rozprzestrzenianie się wśród nie-Żydów stał się okazją do zyskania przez Kościół większej świadomości tego, czego dokonał Jezus Chrystus, a także konsekwencji, jakie to wnosi do teologii, praktyki religijnej czy życia społecznego ${ }^{11}$.

\section{Przebieg Soboru Jerozolimskiego}

Według relacji z Ga 2,1-10 przybycie Pawła do Jerozolimy miało charakter wizyty prywatnej, podjętej „na skutek otrzymanego objawienia” (kata apokalypsin). Do konfrontacji z przeciwnikami dochodzi na forum publicznym, jednak charakter zgromadzenia nie wydaje się być bardzo sformalizowany, jako że wspomniani powyżej „fałszywi bracia” byli w stanie „wedrzeć się” na nie. Użyty w tym przypadku czasownik pareiserchomai sugeruje wejście ze złymi intencjami, albo wejście na sposób nieuprawniony.

W opowiadaniu z $\mathrm{Dz} 15$ sytuacja przedstawia się w sposób bardziej sformalizowany. Przede wszystkim Paweł, Barnaba i ich towarzysze są oficjalnymi wysłannikami wspólnoty antiocheńskiej. W tekście co prawda czasownik „wyznaczyli” (etaksan) nie posiada podmiotu, jednak kontekst pozwala nam domyślać się, iż tymi, którzy wysyłają tę grupę są odpowiedzialni za tę gminę.

\footnotetext{
10 Zob. J. Ciecieląg, Kogo uważano za Żyda w starożytności?, „Studia Judaica” 2005, 8, s. 42.

11 Zob. M. Rosik, Kościót a Synagoga (30-313 po Chr.). Na rozdrożu, Wrocław 2016, s. 22-23.
} 
Znaczyłoby to, że w samej Antiochii opinia przedstawiona przez Pawła miała przewagę $^{12}$. Możliwe jest także, że wysłannicy reprezentują jedynie tę część swojej wspólnoty, która pochodzi z pogaństwa. Za taką opinią przemawia fakt, iż jedynie ta grupa jest adresatem ostatecznej odpowiedzi udzielonej przez „sobór”. Niezależnie od tego wydaje się, że od odpowiedzialnych wspólnoty jerozolimskiej oczekuje się rozstrzygnięcia, które będzie wiążące dla wszystkich chrześcijan. Może to oznaczać, że gmina ta sprawowała swego rodzaju funkcję patrona w stosunku do młodszych kościołów. Bardziej prawdopodobne jest jednak, że szczególny autorytet tej wspólnoty wynikał z obecności Apostołów. W odróżnieniu bowiem od praktyki Pawła, Łukasz konsekwentnie rezerwuje ten tytuł jedynie dla członków Kolegium Dwunastu. Jednocześnie postaci poszczególnych Apostołów, zwłaszcza Piotra, przedstawiane są jako paradygmaty prawdziwych świadków Chrystusa, których szczególnym zadaniem jest zarówno zebranie Nowego Izraela jak i troska o historiozbawczą ciągłość od Jezusa do Kościoła ${ }^{13}$.

Czas podróży wysłannicy wykorzystują jako okazję do nawiedzenia wspólnot w Fenicji i Samarii (Dz 15,3). Mowa jest tutaj o kościołach powstałych na skutek misji „hellenistycznych”, rozpoczętych po śmierci Szczepana ${ }^{14}$. Nie ma tu więc miejsca na kontrowersje, które pojawią się w Jerozolimie. $\mathrm{Z}$ tego samego powodu trudno przypuszczać, iż była to swego rodzaju akcja agitacyjna, mająca na celu uzyskanie poparcia. Jak zauważymy w dalszej części, decyzje „soboru” nie były uzależnione od jakiegokolwiek plebiscytu. Należy zgodzić się raczej z tezą, że wzmianka ta jest „Łukaszowym przygotowaniem terytoriów, do których skierowane zostanie przyszłe przesłanie soboru" ${ }^{15}$.

Po przybyciu do Jerozolimy wysłannicy zostają przyjęci przez „Kościół, Apostołów i starszych” ( $\mathrm{Dz}$ 15,4). Tutaj również rozpoczynają od opowiadania o „wielkich rzeczach, jakich Bóg przez nich dokonał”. Ich świadectwo zostaje jednak przerwane przez interwencję przedstawicieli nawróconych faryzeuszów, którzy powtarzają żądanie przedłożone wcześniej w Antiochii - wszyscy nawróceni poganie powinni przyjąć znak obrzezania i zobowiązać się do przestrzegania Prawa Mojżeszowego. Dopiero to wydarzenie staje się powodem do zwołania posiedzenia, na którym cała sprawa ma być wyjaśniona. Warto przy tej okazji nadmienić, że następuje w tym miejscu pełniejsza identyfikacja przeciwników Pawła: o ile w Antiochii określani są oni jako „niektórzy” (tines), o tyle w tym

12 Zob. F. F. Bruce, The Book of Acts, s. 476.

13 Zob. A. J. Najda, Historia paradygmatyczna w Dziejach Apostolskich, s. 239-240.

14 Zob. J. D. G. Dunn, The Acts of the Apostles, Grand Rapids 1996, s. 314.

15 T. Tułodziecki, Sobór Jerozolimski jako następstwo sporu apostolskiego w Antiochii (Dz 15,135), „Biblica et Patristica Thoruniensia” 2008, 1, s. 148. 
miejscu dopowiedziane jest, że traktuje się o nawróconych faryzeuszach. Przedstawiciele tego odłamu judaizmu mieli większą łatwość w przyjęciu orędzia chrześcijańskiego, jako że uznawali wiarę w Zmartwychwstanie, co Paweł skrzętnie wykorzysta w swoim procesie przed Sanhedrynem (Dz 23, 1-11). W tym jednak miejscu okazuje się, że w odróżnieniu od niego w głębi serca pozostali formalistami, przywiązanymi do zachowywania litery Prawa ${ }^{16}$.

Właściwe obrady w opisie Łukasza składają się z kilku etapów. Pierwszym $z$ nich jest „dłuższe roztrząsanie” (pollēs de dzētēseōs). Możemy domniemywać, iż był to czas, w którym każdy z uczestników spotkania mógł zabrać głos, aby przedstawić swoją opinię. Ten moment kończy się, gdy głos zabiera Piotr. Jego wypowiedź dzieli się wyraźnie na dwie części: w pierwszej (Dz 15, 7-9) odwołuje się do doświadczenia, w którym rozpoznaje działanie samego Boga, w drugiej zaś ( $\mathrm{Dz}$ 15, 10-11) przedstawia konsekwencje, które z tego wynikają ${ }^{17}$. Należy przy tym zauważyć, że uznawanie Prawa za niemożliwe do wypełnienia nie wynika z teologii judaistycznej czy Pawłowej, lecz jest przekonaniem chrześcijan $z$ czasów Łukasza ${ }^{18}$. Z kolei określenie doktrynalne „zbawienie przez łaskę” odnajdujemy w różnych wariantach w listach Pawła. Mamy tu bowiem do czynienia z zabiegiem literackim, poprzez który Łukasz wpisuje się w sposób narracji historii rozpowszechniony w świecie hellenistyczno-rzymskim. W tym sensie wypowiedzi poszczególnych osób nie są odtworzeniem ich rzeczywistych przemówień, lecz są środkiem literackim mającym na celu przedstawienie swego rodzaju summarium teologii całej księgi ${ }^{19}$.

Kolejny etap to wysłuchanie sprawozdania z działalności misyjnej Barnaby i Pawła, które odbywa się już bez zakłóceń. Jakkolwiek ich opowiadanie o „cudach i znakach”, których byli świadkami niewątpliwe wywarło wpływ na uczestników obrad, to jednak służą one jedynie za dodatkową egzemplifikację tego, o czym mówił wcześniej Piotr. Być może dlatego ich przemowa nie jest przytoczona nawet w skrócie. Dodatkowym motywem dla takiego przedstawienia sprawy jest niewątpliwie fakt, że uczestniczą w odbywającym się spotkaniu w charakterze świadków raczej, niż pełnoprawnych uczestników. W tym zgromadzeniu ich autorytet nie jest porównywalny z autorytetem Apostołów, których mowy są przedstawiane ${ }^{20}$.

\footnotetext{
16 Por. F. F. Bruce, The Book of Acts, s. 479.

17 Zob. T. Tułodziecki, Sobór Jerozolimski jako następstwo sporu apostolskiego w Antiochii, s. 149 .

18 Por. H. van der Sandt, An Explanation of Acts 15,6.21 in the Light of Deuteronomy 4,29-35 (LXX), „Journal for the Study of the New Testament” 1992, 46, s. 73.

19 Zob. A. J. Najda, Historia paradygmatyczna w Dziejach Apostolskich, s. 145.

20 Por. F. F. Bruce, The Book of Acts..., s. 485.
} 
Po tym wystąpieniu głos zabiera Jakub, brat Pański. Warto już na wstępie zaznaczyć, że w opowiadaniu Łukaszowym odgrywa on rolę paradygmatyczną na kilku płaszczyznach. Jest więc w pierwszym rzędzie wzorem człowieka stojącego na czele gminy i biorącym za nią odpowiedzialność. Z jednej strony, jego zdanie ma charakter obowiązujący, z drugiej, jednak przedstawiony jest jako ten, który uważnie słucha wszystkich racji i jako pierwszy szuka rozwiązań kompromisowych. Ponadto jest paradygmatem rozumienia i interpretowania Pisma Świętego. Taki sposób przedstawienia tej postaci możemy zaobserwować w opowiadaniu o Soborze Jerozolimskim ${ }^{21}$. Jego wystąpienie rozpoczyna się od krótkiego podsumowania wypowiedzi Piotra, o którym mówi używając jego hebrajskiego imienia. To otwierające zdanie naznaczone jest pewnym paradoksem, który nie do końca jest zauważalny w tłumaczeniu na język polski. W tradycji Starego Testamentu istnieje bowiem dość ostro zaznaczona opozycja pomiędzy Ludem (hbr. 'ām) i narodami (hbr. gôjim). W tej wypowiedzi Lud jest wybierany spośród pogan. Właśnie na uzasadnienie tej paradoksalnej tezy został przywołany cytat z Am 9,11-12. Pewną wątpliwość stanowi fakt, iż cytat ten przytoczony jest za Septuaginta, aczkolwiek możliwe jest, że mamy tu do czynienia z odniesieniem do innego wariantu tekstualnego, niż ten znany z dzisiejszej Biblii Hebrajskiej ${ }^{22}$. Jakub stosuje w tym przypadku znany rabinom sposób argumentowania, który polega na przytoczeniu wcześniejszego proroctwa dla poparcia stawianej tezy. Cytowany tekst odczytywany był jako mesjanistyczny wśród Żydów współczesnych Apostołom. Z punktu widzenia chrześcijan czasy mesjańskie już nastały, zaś przyjęcie pogan jako uprawnionych członków Ludu Bożego jest jednym ze znaków realizowania się zapowiedzi prorockich ${ }^{23}$.

W następnej części swojej wypowiedzi Jakub przedstawia propozycję rozwiązania istniejącego konfliktu. Jakkolwiek nie ma tu wprost odniesienia do obrzezania to jednak zachęta, aby nie „niepokoić” (mē parenochlein) chrześcijan pochodzących z pogaństwa jest czytelną sugestią, że przyjęcie tego znaku nie jest konieczne do Zbawienia. Pojawiające się następnie tzw. klauzule Jakubowe wydają się nawiązywać do przepisów zawartych w Kpł 17,8-16 i 18,6-18, które mają odnosić się także do obcokrajowców zamieszkujących ziemie Izraela. Zachodnia tradycja tekstualna pomija zakaz spożywania tego, co uduszone,

21 Zob. A. J. Najda, Historia paradygmatyczna w Dziejach Apostolskich, s. 291.

22 Szerzej na temat pochodzenia tego cytatu możemy znaleźć w: M. Braun, James Use of Amos at the Jerusalem Council: Steps Toward a Possible Solution of the Textual and Theological Problems, ,Journal of the Evangelical Theological Society” 1977, 20, s. 112-113. Por. T. Tułodziecki, Sobór Jerozolimski jako następstwo sporu apostolskiego w Antiochii, s. 152-153.

23 Por. F. F. Bruce, The Book of Acts, s. 489. 
dodaje zaś na końcu tzw. złotą regułę $(\mathrm{Mt} \mathrm{7,12})^{24}$, ograniczając w ten sposób liczbę klauzul do trzech. Zakazy obejmują w tym przypadku bałwochwalstwo, nierząd i krew (czyli zabójstwo), a więc pierwotną listę grzechów głównych znaną w Kościele. Tradycja ta jest zapewne późniejszą próbą odczytania w duchu etycznym wskazań mających charakter legalistyczny. Przemawia za tym następujące w w. 21 odwołanie do znajomości Prawa Mojżeszowego, które jest odczytywane w synagogach na całym świecie. W myśl interpretacji rabinicznej, rozpowszechnionej w czasach apostolskich, przymierze zawarte $z$ Noem rozciąga się na wszystkich jego potomków, tj. całą ludzkość. Jakkolwiek tekst $\operatorname{Rdz}$ 9,4 zawiera jedynie zakaz spożywania krwi, to jednak ta popularna interpretacja rozciągała na pogan wszystkie przykazania, które odnosiły się do nich w Torze ${ }^{25}$.

Propozycja rozwiązania zaprezentowana przez Jakuba jest zatem rzeczywiście kompromisowa. Przede wszystkim potwierdza za pomocą argumentu skrypturystycznego, że etnochrześcijanie są pełnoprawnymi członkami nowego Ludu Bożego nie poprzez włączenie do „starego” Izraela, ale właśnie jako przedstawiciele narodów pogańskich, co jest wypełnieniem obietnic mesjańskich Starego Testamentu. Z kolei „klauzule Jakubowe”, rozciągające na nich postanowienia Prawa odnoszące się do cudzoziemców, kreują sytuację, w jakiej obie grupy mogą utrzymywać wzajemną jedność, zwłaszcza wspólnotę stołu ${ }^{26}$.

To rozwiązanie wydaje się kończyć dyskusję. W dalszej części opowiadania zostają podjęte decyzje o wysłaniu do Antiochii oficjalnych delegatów gminy jerozolimskiej wraz z listem zawierającym postanowienia końcowe „soboru”. Konieczność wysłania takiej grupy wynika z faktu, że w Łukaszowym opowiadaniu cały problem powstał w wyniku działania nieautoryzowanych przedstawicieli tej wspólnoty, co zostaje podkreślone w liście. Dokument ten przedstawiony jest jako wiążący dla Kościołów w Antiochii, Syrii i Cylicji. Sformułowana jest w nim zachęta do podporządkowania się zakazom wyszczególnionym uprzednio w „klauzulach Jakubowych”. W wyrażeniu „ciężar” (baros) widzimy jednak raczej nawiązanie do wcześniejszej wypowiedzi Piotra $(\mathrm{Dz} 15,10)$.

Dla naszych rozważań najistotniejsze znaczenie ma uroczysta formuła zawarta w w. 28: „postanowiliśmy bowiem, Duch Święty i my” (edoksen gar tō pneumati tō hagiō kai hēmin). Wyrażenia takiego rodzaju nie spotykamy w żadnym innym miejscu w Nowym Testamencie. Wskazuje ono na zdumiewającą samoświadomość zebranej wspólnoty, która w kolektywnie podjętej decyzji widzi

24 Zob. E. Dąbrowski, Dzieje Apostolskie. Wstęp - przekład z oryginalu - komentarz, Pismo Święte Nowego Testamentu V, Poznań 1961, s. 356-357.

25 Zob. T. R. Hanneken, Moses Has His Interpreters: Understanding the Legal Exegesis in Acts 15 from the Precedent Jubilees, „Catholic Biblical Quarterly” 2015, 74/4, s. 686-706.

26 Por. A. J. M. Wedderburn, The "Apostolic Decree”: Tradition and Redaction, „Novum Testamentum" 1993, 35/4, s. 362-389. 
w pierwszym rzędzie działanie Ducha Świętego. Właśnie ta samoświadomość pozwala nam stwierdzić, iż opowiadanie o Soborze Jerozolimskim zawarte w $\mathrm{Dz}$ 15, 1-29 pomyślane jest jako historia paradygmatyczna, w której przedstawiony jest właściwy sposób konfrontowania się z problemami powstającymi w łonie Kościoła. Jednocześnie, z racji na przedstawiony sposób postępowania, możemy mówić o paradygmacie modelu koncyliarności.

\section{Opis Soboru Jerozolimskiego jako paradygmat koncyliarnego rozwiązywania sporów}

W swojej książce A. Najda w sposób przekonujący udowadnia, iż historia opowiedziana w Dziejach Apostolskich w wielu przypadkach pełni funkcję paradygmatyczną. Jest to widoczne w sposób szczególny w opowiadaniu o Soborze Jerozolimskim, w którym przenikają się trzy omawiane przez tego autora typy paradygmatów: paradygmat historii, osób i wspólnoty Kościoła ${ }^{27}$. Spróbujemy przyjrzeć się bliżej tej sprawie, zwłaszcza w kontekście ostatniego ze wspomnianych typów.

Podobnie jak w wielu innych miejscach Dziejów Apostolskich, także tutaj jasno jest przedstawiona hierarchiczna struktura Kościoła. Dotyczy to także relacji między poszczególnymi gminami, wśród których wspólnota jerozolimska wydaje się odgrywać szczególną rolę. Już we wprowadzeniu do opowiadania zostało przedstawione, że źródłem występujących kontrowersji jest pojawienie się w tamtejszej gminie chrześcijan pochodzących z Judei. Ich zdanie traktowane jest poważnie, pomimo że nie występują z oficjalnym upoważnieniem ze strony swojej wspólnoty. Wskutek podziałów, które przybierają coraz bardziej ostry charakter, gmina antiocheńska decyduje się na wysłanie do Jerozolimy swoich przedstawicieli. Mają oni za zadanie przedstawić całą kwestię osądowi „Apostołów i starszych”. Z tekstu jasno nie wynika, czy autorytet wspólnoty jerozolimskiej wynika z pewnej hierarchii istniejącej między poszczególnymi gminami. Taka sytuacja do pewnego stopnia odpowiadałaby znanej relacji „patron/klient”, która była modelem dla wielu wzajemnych odniesień w ówczesnym świecie ${ }^{28}$. W opowiadaniu Łukaszowym na pierwszy plan wysuwa się jednak fakt obecności w tamtejszej wspólnocie Apostołów. Jak już zauważyliśmy wcześniej, tytuł ten w Dziejach Apostolskich zarezerwowany jest dla przedstawicieli grona Dwunastu ${ }^{29}$. Z racji na ich funkcję (paradygmat osób)

27 Zob. A. J. Najda, Historia paradygmatyczna w Dziejach Apostolskich, s. 378.

28 Zob. B. J. Malina, Patronage, [w:] Handbook of Biblical Social Values, red. J. J. Pilch, B. J. Malina, Paebody 1998, s. 151-155.

29 Wyjątkiem jest ustęp z Dz 14,4.8, gdzie tytułem tym określeni są Paweł i Barnaba. Wydaje się jednak, że mamy tu do czynienia z sytuacją wyjątkową, w której do urzędu apostolskiego 
ich szczególnym obowiązkiem było zapewnienie ciągłości historycznozbawczej misji Chrystusa i jej kontynuacja w życiu młodego Kościoła ${ }^{30}$. Tę szczególną rolę widać wyraźnie w scenie wyboru Macieja na miejsce Judasza: jedną $z$ oczekiwanych od kandydata cech jest towarzyszenie Jezusowi od momentu chrztu w Jordanie.

Hierarchiczna struktura Kościoła widoczna jest wewnątrz poszczególnych gmin, co znajduje swój wyraz w konkretnych sformułowaniach. I tak, zaraz po przybyciu do Jerozolimy Paweł i Barnaba zostają przywitani przez „Kościół, Apostołów i starszych” (w. 4). W podejmującym decyzje zgromadzeniu biorą udział „Apostołowie i starsi” (w. 6, do tej samej grupy posłani zostali Paweł, Barnaba i ich towarzysze w w. 3). Ostateczną decyzje o wysłaniu oficjalnej delegacji z listem do gminy w Antiochii podejmuja "Apostołowie i starsi wraz z całym Kościołem” (w. 22). Sformułowanie zawarte w adresie listu (w. 23) nastręcza pewnych trudności. Najważniejsze kodeksy uncjalne mają tutaj formulę „Apostołowie i starsi bracia” (hoi apostoloi kai hoi presbyteroi adelfoi), która z punktu widzenia gramatycznego jest dość niezwykła. Trudność tę inne kodeksy rozwiązują, dodając przed ostatnim określeniem spójkę i rodzajnik (kai hoi adelfoi), przez co dodają do nadawców listu kolejna grupę, czyli „braci” tj. wszystkich wiernych. Wydaje się jednak, że to drugie rozwiązanie należy traktować jako lectio facilior ${ }^{31}$. W takim przypadku należałoby traktować określenie „bracia” jak wspólne określenie grupy „Apostołów i starszych”, którzy przesyłają list „braciom pogańskiego pochodzenia w Antiochii, w Syrii i w Cylicji”. Jako nadawcy są więc wymienieni jedynie ci, którzy pełnią w gminie określone funkcje, jakkolwiek decyzja podejmowana jest przez „cały Kościól”.

Model koncyliarny, prezentowany przez Łukasza nie jest więc całkowicie „demokratyczny”. Jakkolwiek każdy może zabrać głos w dyskusji, to jednak nie każda wypowiedź ma ten sam ciężar, przy czym autorytatywność danej wypowiedzi uzależniona jest do pewnego stopnia od urzędu, jaki pełni wypowiadający się. Sposób prowadzenia narracji w wersach 4-6 zdaje się wskazywać, że całkowita swoboda zabrania głosu dotyczy wszystkich wiernych jedynie przed rozpoczęciem właściwych obrad, podczas których mogą wyrażać swoje

włączeni byli ci, którzy zostali wysłani z misją głoszenia Ewangelii przez swoje wspólnoty. W niczym to nie narusza szczególnej roli, jaką miało do odegrania kolegium Dwunastu (w dziele Łukaszowym terminy Apostołowie i Dwunastu są traktowane wymiennie). Zob. A. J. Najda, Historia paradygmatyczna w Dziejach Apostolskich, s. 238-239.

30 Zob. M. Dömer, Das Heil Gottes. Studien zur Theologie des lukanischen Doppelwerkes, BBB 51, Köln - Bonn 1978, s. 131.

31 Tak samo jak pojawiające się niekiedy świadectwa, w których słowo adelfoi jest pominięte. Por. E. Dąbrowski, Sobór Dzieje Apostolskie. Wstęp - przekład z oryginatu - komentarz, Pismo Święte Nowego Testamentu V, Poznań 1961, s. 358. 
opinie jedynie do tego uprawnieni. Warto także podkreślić, iż od strony formalnej opisane obrady są zgromadzeniem wyłącznie gminy jerozolimskiej. Widzimy to w przypadku wspomnianej w w. 12 relacji Barnaby i Pawła, którzy nie tyle przedstawiają swoją opinię jako równoprawni uczestnicy „soboru”, co zdają sprawozdanie ze swojej misji i z tego, czego byli świadkami w trakcie jej trwania $^{32}$.

To ostatnie stwierdzenie zwraca naszą uwagę na właściwy przedmiot zainteresowania obrad „soboru”. Jakkolwiek wielu badaczy podkreśla istnienie kilku grup, które reprezentują w trakcie obrad sprzeczne opinie istniejące w łonie Kościoła ${ }^{33}$, to jednak w opisie Łukaszowym nie ten fakt wysuwa się na pierwsze miejsce. Istotne miejsce zajmuje tutaj refleksja nad dziełami, których Bóg dokonuje w historii. Piotr w swoim wystąpieniu nawiązuje do wydarzeń $z$ domu Korneliusza, gdzie decydującą rolę odgrywa fakt udzielenia daru Ducha Świętego poganom. Apostoł nie tyle przedstawia swoją opinię, co wskazuje na wybranie, którego autorem jest sam Bóg. Podobną sytuację rozpoznajemy w sprawozdaniu Pawła i Barnaby: obaj misjonarze opowiadają przede wszystkim o „wielkich cudach i znakach, jakich dokonał Bóg przez nich wśród pogan” (w.12). Również Jakub nawiązuje do faktu, o którym wcześniej opowiadał Piotr. W jego argumentacji nacisk położony jest jednak na inne dzieło Boga, jakim są „„łowa Proroków”. Sposób prowadzenia narracji wskazuje zatem jednoznacznie, że w czasie obrad dochodzi nie tyle do ucierania się kompromisu pomiędzy przeciwstawnymi opiniami, ile do uważnej refleksji nad zaistniałymi wydarzeniami, oświeconej dodatkowo odwołaniem do słów Pisma Świętego. To właśnie ten fakt sprawia, że w ostateczności Zgromadzenie Soborowe nie uważa siebie za głównego autora zaproponowanego ostatecznie rozwiązania. Świadczy o tym zastosowanie bezprecedensowej formuly w korpusie listu: „postanowiliśmy bowiem, Duch Święty i my” (edoksen gar tō pneumati tō hagiō kai hēmin, w.28). Członkowie Kolegium mogą wymienić Trzecią Osobę Trójcy Świętej jako głównego protagonistę Zgromadzenia i autora rozwiązania, gdyż sami siebie uważają za posłusznych wykonawców Jego woli.

W opisanej scenie widać także paradygmat Kościoła. Z naszego punktu widzenia najbardziej istotne jest tu przedstawienie paradygmatu Kościoła jako wspólnoty hierarchicznej, cechującej się jednością i miłością 34 . Jako że pierwszy $z$ tych elementów zarysowaliśmy powyżej, skupimy się teraz na dwu pozostałych.

Pozornie mówienie o jedności w przypadku opowiadania o kontrowersjach wydaje się być nie na miejscu. Całość narracji przedstawiona jest jednak w taki

\footnotetext{
32 Zob. F. F. Bruce, The Book of Acts, s. 485.

33 Zob. M. Rosik, Kościót a Synagoga..., s. 166.

34 Por. A. J. Najda, Historia paradygmatyczna w Dziejach Apostolskich, s. 356-369.
} 
sposób, aby właśnie ta cecha Kościoła uwidoczniła się najbardziej. Rozpoczyna się więc od wzmianki o „niemałych sporach i roztrząsaniach” (staseōs kai dzētēeōs ūk oligēs), jakie powstają w Antiochii w wyniku działania przybyszy z Judei. Także w scenie powitania wysłanników w Jerozolimie, ich opowiadanie przerwane jest żądaniem przedstawionym przez nawróconych faryzeuszy. Na zakończenie obrad jednak formułuje się list, w którym decyzja określana jest jako podjęta „jednomyślnie” (homothymadon). Wspólnota zostaje więc odbudowana dzięki wspólnemu pochyleniu się nad dzielącym zagadnieniem w duchu posłuszeństwa woli Bożej.

Paradygmat Kościoła jako wspólnoty miłości widzimy najbardziej w ostatecznych dekretach wydanych przez „sobór”. „Klauzule Jakubowe” nie są bowiem wyrażeniem doktryny, która ma obowiązywać zawsze i wszędzie, ale są raczej wyrazem troski o wspólnotę, w której należy wypracować takie sposoby postępowania, aby nikt nie mógł czuć się urażony. W szczególny sposób dotyczy to sprawowania Eucharystii, która jest wspólnotą stołu i jednocześnie jest największym wyrazem miłości braterskiej ${ }^{35}$. Jakkolwiek więc podjęta decyzja uznaje prawo do przynależności do Kościoła nawróconych pogan, to jednak sugeruje przyjęcie pewnych rozwiązań jako ułatwiających pokojowe współżycie chrześcijan różnego pochodzenia.

Jak mogliśmy zauważyć, opowiadanie zawarte w Dz 15,1-29 przedstawia pewien paradygmat rozwiązywania sporów w Kościele, który możemy określić jako koncyliarny. Przedstawia on kilka cech charakterystycznych, podkreślonych w omawianym tekście. Podsumowując nasze dotychczasowe rozważania przedstawimy je teraz w punktach.

Zgromadzenie Kościoła zdaje sobie sprawę z istnienie nierówności w prawach jak i w obowiązkach poszczególnych członków wspólnoty. Wynika ono bowiem $z$ hierarchicznej natury Kościoła. Ostatecznym autorem takiej nierówności jest sam Bóg, który wybiera określonych ludzi do pełnienia szczególnych zadań.

Zadaniem członków zgromadzenia jest nie tyle przedstawianie własnej opinii czy wręcz próba przekonania do niej innych uczestników. Zgromadzenie takie nie ma bowiem charakteru, który moglibyśmy określić jako „polityczny”. Chodzi tutaj raczej o pokorne poddanie się prowadzeniu Ducha Świętego, które dokonuje się przez uwagę zwróconą na dzieła, których Bóg dokonuje w historii i przez pogłębioną interpretację tekstów Pisma Świętego.

Dla wszystkich uczestników Zgromadzenia istotne jest zachowanie jedności i wzajemnej miłości w łonie Kościoła.

Zgromadzenie charakteryzujące się takimi cechami staje się faktycznie narzędziem w rękach Ducha Świętego, za pomocą którego cała wspólnota

35 Por. V. Kesich, The Apostolic Council at Jerusalem, „St. Vladimir's Seminary Quarterly” 1962, 6/3, s. 112. 
Kościoła jest prowadzona przez swoje dzieje. W omawianym przypadku dotyczy to nie tylko zażegnania sytuacji, która mogłaby spowodować podziały i wzajemną nieufność między poszczególnymi gminami i osobami. Traktuje się tu o rozstrzygnięciu, które z dzisiejszej perspektywy określilibyśmy jako „dogmatyczne”. „Sobór”, do którego doszło w Jerozolimie jest tym momentem, w którym Kościół w pełniejszy sposób zrozumiał samego siebie i misje, jaką ma do wypełnienia w świecie.

We wstępie do niniejszego artykułu zaznaczyliśmy, iż opowiadanie zawarte w Dz 15,1-29 odgrywa szczególną rolę w kompozycji Dziejów Apostolskich. Autor umieszcza je w centralnym miejscu swojej narracji, aby podkreślić doniosłość tego wydarzenia i wagę decyzji podjętych przez Sobór Jerozolimski. Chodzi tu przede wszystkim o określenie, w jaki sposób i na jakich warunkach poganie mogą być przyjęci do wspólnoty Kościoła ${ }^{36}$. Rzeczywiście narracja od tego momentu opowiada o nieustannym progresie misji ewangelizacyjnej wśród narodów, która w ostatnich rozdziałach doprowadzi Pawła do Rzymu - centrum ówczesnego świata. Z naszego punktu widzenia istotnym elementem jest fakt, że ta epokowa decyzja podejmowana jest przez Zgromadzenie o charakterze koncyliarnym. W ten sposób Łukasz buduje pewien paradygmat konfrontowania się z sytuacjami konfliktowymi, które dotyczą zarówno zagadnień praktycznych, jak i doktrynalnych. Nie oznacza to, aby w ten sposób tworzona była i sankcjonowana jakaś konkretna instytucja o charakterze formalnym, pozostająca w określonych relacjach do innych urzędów w Kościele. Chodzi tu raczej o pokazanie pewnego modelu, w którym dochodzenie do jednomyślności jest faktycznie wsłuchaniem się w głos Ducha Świętego, który prowadzi swój kościół przez historię.

Słowa kluczowe: Dz 15,1-29, kryzys antiocheński, Sobór Jerozolimski, kolegialność.

\section{Bibliografia:}

1. Bennema C., The Ethnic Conflict in Early Christianity. An Appraisal of Bauckham's Proposal on the Antioch Crisis and the Jerusalem Council, „Journal of the Evangelical Theological Society" 2013, 56/4.

2. Braun M., James Use of Amos at the Jerusalem Council: Steps Toward a Possible Solution of the Textual and Theological Problems, ,Journal of the Evangelical Theological Society" 1977, 20.

3. Bruce F. F., The Book of Acts, (New International Commentary on the New Testament), Grand Rapids 1988.

36 Por. F. F. Bruce, The Book of Acts, s. 472. 
4. Chrostowski W., Między Synagoga a Kościołem. Dzieje św. Pawła, Kraków 2015.

5. Ciecieląg J., Kogo uważano za Żyda w starożytności?, „Studia Judaica” 8 (2005).

6. Dunn J. D. G., The Acts of the Apostles, Grand Rapids 1996.

7. Dömer M., Das Heil Gottes. Studien zur Theologie des lukanischen Doppelwerkes, BBB 51, Köln - Bonn 1978.

8. Dąbrowski E., Dzieje Apostolskie. Wstęp - przekład z oryginalu - komentarz, Pismo Święte Nowego Testamentu V, Poznań 1961.

9. Gnilka J., Pawet z Tarsu. Apostot $i$ świadek, Kraków 2001.

10. Hanneken T. R., Moses Has His Interpreters: Understanding the Legal Exegesis in Acts 15 from the Precedent Jubilees, „Catholic Biblical Quarterly” 2015, 74/4.

11. Józef Flawiusz, Antiquitates judaicae.

12. Kesich V., The Apostolic Council at Jerusalem, „St. Vladimir's Seminary Quarterly” 6/3 (1962).

13. Malina B. J., Patronage, [w:] Handbook of Biblical Social Values, red. J. J. Pilch, B. J. Malina, Paebody 1998, s. 151-155.

14. Mickiewicz F., Działalność misjonarska św. Piotra poza Palestyna w świetle literatury nowotestamentowej, „Collectanea Theologica” 2019, 89/3.

15. Najda A. J., Historia paradygmatyczna w Dziejach Apostolskich, Warszawa 2011.

16. Rakocy W., Pawet Apostol. Chronologia życia i pism, Częstochowa 2008.

17. Robertson C.K., Proto-Conciliarism in Acts 15, „Sewanee Theological Review” 2018, 61/2, s. 417-423.

18. Rosik, M. Kościól a Synagoga (30-313 po Chr.). Na rozdrożu, Wrocław 2016.

19. Sandt H. van der, An Explanation of Acts 15,6.21 in the Light of Deuteronomy 4,2935 (LXX), „Journal for the Study of the New Testament” 1992, 46.

20. Schille G., Die Apostelgeschichte, Leipzig 1989.

21. Tułodziecki T., Sobór Jerozolimski jako następstwo sporu apostolskiego w Antiochii (Dz 15,1-35), „Biblica et Patristica Thoruniensia” 2008, 1.

22. Wedderburn A. J. M., The "Apostolic Decree”: Tradition and Redaction, „Novum Testamentum" 1993, 35/4. 